\title{
Implications of Illicit Financial Flows on Zimbabwe's Development
}

\section{Jeffrey Kurebwa}

Department of Peace and Governance, Bindura University of Science Education, P. Bag 1020, Bindura, Zimbabwe Email: jeffkurebwa2015@gmail.com
Article History

Received: 28 December, 2020

Revised: 9 May, 2021

Accepted: 12 June, 2021

Published: 18 June, 2021

Copyright (C) 2021 ARPG \&

Author

This work is licensed under the Creative Commons Attribution International

\section{(ㄷ) (i)}

Commons Attribution License

4.0

\begin{abstract}
Illicit Financial Flows (IFFs) is a major challenge to Zimbabwe's development. They have a direct impact on the country's stability to raise, retain and mobilize its own resources to finance sustainable economic development. The study finds that Zimbabwe lost over US\$32.179 billion during the period 2000 to 2020 . The study relies on normative and legal arguments to justify the effects of illicit financial flows. The problems with IFFs are that they are not only illicit but that their effect spreads far beyond their immediate area of occurrence. Zimbabwe has suffered irreparable damage because of illicit financial flows. IFFs are mainly driven by the desire to hide wealth and to evade taxes; perpetrators clearly do not respect the obligations of citizenship. Financial flows are crucial for poor countries and have played an important role in Zimbabwe. Since not all financial flows are good for development, the integration of poor countries into the global financial system poses opportunities as well as risks.
\end{abstract}

Keywords: Illicit financial flows; Financial outflows; Development; Trade mis-invoicing; Zimbabwe; Africa; Illegal; Zimbabwe.

\section{Introduction}

Illicit financial flows (IFFs) have been identified as the biggest challenge to development. They are increasingly becoming a source of concern for developing countries (Massa, 2014). Every year developing countries experience a massive volume of capital flight which is illegally or illicitly transported to developed countries. In some cases large amounts of IFFs are transferred within the same country. IFFs drain capital and tax revenue from developing countries. Moving capital out of the country illicitly enables tax evaders, corrupt officials, businesspeople, and criminals to better protect their funds from seizure. Goal 16 of the Sustainable Development Goals (SDGs) addresses corruption, and Target 16.4 specifically concerns IFFs. It states that:

By 2030, significantly reduce illicit financial flows and arms flows, strengthen the recovery and return of stolen assets and combat all forms of organized crime.

Achieving the SDGs will require considerably more resources than can be afforded by public finance. By curbing IFFs and recovering stolen assets, governments have the opportunity to unlock much needed resources to close the financial gap to achieve the SDGs.7 Moreover, combating IFFs is an important element of tackling the crime, corruption, and violent extremism that threaten stability and economic development.

IFFs threaten the fundamental aspects of development, such as the rule of law, the quality and accountability of democratic institutions and, the broader social trust (Reuter, 2017). These illicit outflows largely exceed aid funds and a great proportion of the flows are likely to stem from corruption (Global Financial Integrity, 2017). These funds could otherwise be used to finance education, infrastructure, health care, and other vital elements of sustainable development. By reducing IFFs, governments will have more public funds available to invest in the development of their countries. Strengthening the rule of law and effectively prosecuting offenders, increase citizens' trust in state institutions and contributing a country's stability. This study therefore focuses on the implications of IFFs to development in Zimbabwe. It is estimated that Zimbabwe lost over US\$32,179 billion through IFFs since 2000 (The Zimbabwe Independent, 2020).

\section{Literature Review}

This section seeks to provide an understanding of the various definitions of IFFs as defined by various scholars and organisations involved in combating IFFs.

\subsection{Defining Illicit Financial Flows}

There is no clear consensus on a single definition of IFFs, since the word illicit can be understood to mean both illegal and legal, but legally or morally contentious and otherwise not fully legitimate (Fontana and Hansen-Shino, 
2012). There are many reasons why finance flows out of African countries illicitly, usually in contravention of national or international rules. There are a variety of definitions of IFFs in the literature. Epstein (2005) defines IFFs as "capital taken abroad in a hidden form, perhaps because it is illegal, or perhaps because it goes against social norms, or perhaps because it might be vulnerable to economic or political threat". Other scholars have also summarised IFFs as money illegally earned, transferred or used (Baker, 2005; Kar, 2011; Reuter, 2012). These flows of money are in violation of laws of their countries of origin, or during their movement or use, and are therefore considered illicit. This study emphasises the issue of illegality of such outflows across countries. A legal act in one country does not nullify the intent and purpose of such outflows of hiding money even if it was legitimately earned. The term 'illicit' is also a fair description of activities that while not strictly illegal in all cases, go against established rules and norms, including avoiding legal obligations to pay tax (Cobham, 2014).

The term IFF underpins a different manifestation of the state-market relationship to that characterising the conventional work on capital flight. Blankenburg and Khan (2012) refer to IFFs as the portfolio choice. These follow standard mainstream neoclassical models of utility and profit maximisation while capital flight is explained as a portfolio diversification response by rational economic agents to higher foreign returns relative to domestic returns on assets. The emphasis on criminal, corrupt, and commercial activities of IFFs underlines a policy response that encourages a more active role for the State and that highlights the need for a better regulatory environment through enforcement of national and global standards of financial transparency and democratic accountability (Haken, 2011).

According to the Organisation for Economic Co-operation and Development OECD (2013), IFFs are crossborder capital transactions either concealing illegal activities or facilitating them. It argues that 'There are various definitions of illicit financial flows, but essentially they are generated by methods, practices and crimes aiming to transfer financial capital out of a country in contravention of national or international laws. In practice illicit financial flows range from something as simple as a private individual transfer into private accounts abroad without having paid taxes, to highly complex schemes involving criminal networks that set up multi-layered multijurisdictional structures to hide ownership" (Organisation for Economic Co-operation and Development OECD, 2013).

The World Bank appears to give a broader definition than the one suggested by the OECD. The organisation explains the phenomenon of illicit financial flows as financial flows that have a direct or indirect negative impact on (long-term) economic growth in the country of origin (depending on the particular national development situation). This definition underscores the outcome of a particular activity. The breach of the law is not required to classify a particular action as illicit. Instead, the activity is categorised as illicit if it hampers economic growth (Blankenburg and Khan, 2008).

Global Financial Integrity (2013a), defined illicit financial outflows as 'all unrecorded private financial outflows involving capital that is illegally earned, transferred or utilised, generally used by residents to accumulate foreign assets in contravention of applicable capital controls and regulatory frameworks'. The basic assumption in this definition is that the transfers in question take place via unregistered channels because their background or purpose is illegal. Similar to the definition proposed by the OECD, the GFI requires that a particular activity is illegal. The OECD and the GFI both limit the definition of IFFs to illegal actions. Those financial flows that are against the spirit of law or are just not criminalised in a particular country but as such are perceived as unacceptable are not covered (Organisation for Economic Co-operation and Development OECD, 2013).

Other definitions also include funds that are illicitly earned, transferred, or used within the same country (Erskine and Eriksson, 2018). GIZ in its programme Combating Illicit Financial Flows argues that domestic IFFs are equally important to address in a development perspective. It defines IFFs as 'all movements of capital or other assets which are illegal by virtue of their origin (criminal activity, tax evasion, corruption), the target/ purpose (terrorist financing), or due to the modalities of their transfer (violation of sanctions or avoidance of oversight mechanisms).' In order to tackle IFFs within and between states, both the measures at domestic level (to tackle purely domestic IFFs) and those at the international level (to tackle cross-border IFFs) must be applied (Dolve and Mullard, 2018).

The above definitions represent a major departure from the dominant notion of capital flight. Capital flight is understood as the movement of funds abroad in order to secure better returns, usually in response to an unfavourable business environment in the country of origin (Kant, 2002). Capital flight may be legal or illegal. However, IFFs present new conceptual conjecture that departs from capital flight both conceptually and in policy terms. The term IFFs reflects a more narrow definition that focuses unrecorded capital flows that derive from criminal, corrupt (bribery and theft by government officials) and commercial activities (Baker, 2005). The focus on hidden resources and their potential impact on development place the issue of capital flight firmly in the broader realm of international political economy which emphasises the role of governance at both origins as well as at the destinations. This stand in sharp contrast to the conventional models of capital flight, which tend to place the burden on developing countries rather than understanding the shared responsibility between developed and developing countries.

Income from illegal activities transferred across borders is considered as the first group of IFFs (Baker, 2005). The original sources of these IFFs can be both illegal (drug trafficking) and legal (legitimately generated funds can be transferred in an illicit way to another country for the purpose of reducing tax obligations in the country of origin). This group includes illegal activities such as money laundering, drug and human trafficking, smuggling, illegal trade with weapons, counterfeiting, corruption, bribery, customs fraud, or terrorist financing. These illegal activities may be practiced by individuals, corporations, governments or other entities. Cross-border financial flows associated with any of these illegal activities are considered IFFs (Ostfeld, 2013). 
The GFI in its 2017 report established that IFFs from Africa are large and increasing. This finding is valid and is evident across the three main categories of IFFs: commercial, criminal, and corrupt activities. Empirical researches focusing mainly on the merchandise trade sector, found that IFFs from Africa had increased from about US\$20 billion in 2001 to US\$60 billion in 2010. The same conclusions were reached from a review of other related work undertaken by Global Financial Integrity (GFI), the African Development Bank (ADB), the United Nations Development Programme (UNDP) and several Civil Society Organisations (CSOs). Using a different methodology, GFI puts the trend growth of IFFs from Africa over 2002-2011 at 20.2 percent a year. Even those who question the methodologies used to estimate the outflows tend to agree that the problem of IFFs is serious and demands urgent action (Global Financial Integrity, 2017).

\subsection{The Normative and Legal Arguments of IFFs}

The normative and legal arguments have been advanced to define financial flows as illicit. The normative interpretation argues that financial flows are illicit because they hinder development and are regarded as illegitimate from the perspective of an existing consensus about the social good (Blankenburg and Khan, 2012). The legal argument focuses on IFFs as money that is 'earned, transferred or used' in contravention to a country's existing laws (Kar and Freitas, 2012).

Baker (2005) classified illicit money into three main forms, namely:

(i) The proceeds of theft, bribery and other forms of corruption by government officials;

(ii) The proceeds of criminal activities including drug trading, racketeering, counterfeiting, contraband, and terrorist financing; and

(iii) The proceeds of tax evasion and laundered commercial transactions.

Baker (2005), estimates that laundered commercial money through multinational companies constitute the largest component of IFFs, followed by proceeds from criminal activities, and lastly corruption. However, the proceeds of components of IFFs are so intricately connected that makes it virtually impossible to disentangle them into concrete unified units. The cross border nature of IFFs highlights the critical need for a better crosscutting analysis of IFFs as a phenomenon.

The UNODC World Drug Report (2012) estimates that drug trafficking generates between 20-25 percent of all income derived from organised crime and approximately half of the income from transnational organised crime. The trend in illicit drug market seems to be stable and changes in flows can mainly be observed below the surface. This indicates that the illicit drug market is resilient and illicit drug suppliers and users are quick to adapt to preventative measures (UNODC, 2012). Tracking the flows of illicit funds generated by drug trafficking and organised crime and analysing the magnitude and the extent to which these funds are laundered through the world's financial systems remain daunting. A 2009 study by UNODC on 'Transnational Trafficking in West Africa' noted that much of the best information on contraband flows through the region comes from data sources outside the region.

UNODC (2011) estimated that about US\$1.6 trillion (equivalent to about 2.7 percent of global GDP) was available for money laundering activities across the globe. The largest income for transnational organised crime seems to come from illicit drugs, accounting for a fifth of all crime proceeds. It is estimated that the illicit flow of goods, guns, people and natural resources is approximately US\$650 billion. Illicit drug trafficking and counterfeiting are the two largest components of these criminal activities. The market for illicit drug trade is estimated to be worth US $\$ 320$ billion (50 percent) while the market for counterfeiting comprises US\$250 billion (39 percent) and other sources such a human trafficking and illicit oil trade comprise 5 percent and 2 percent of the total respectively (Haken, 2011).

\subsection{Effects of IFFs on Development}

The occurrence of IFFs is first and foremost a governance problem, since good citizenship is the foundation of good government. In as much as IFFs are driven by the desire to hide wealth and to evade taxes, perpetrators clearly do not respect the obligations of citizenship. It is well established in the literature that there is greater government accountability when the bulk of public sector resources derive from taxpayers, who almost always demand to know how their tax monies are being used (Baker, 2005). It is also a governance problem in the sense of weak institutions and inadequate regulatory environments. IFFs accordingly contribute to undermining state capacity. To achieve their purposes, the people and corporations behind IFFs often compromise state officials and institutions. If left unchecked, these activities lead to entrenched impunity and the institutionalisation of corruption (Manton and Daniel, 2012).

Given the well-known dependence of several African countries on significant amounts of ODA, the loss of resources through IFFs can only serve to deepen reliance on donors. Such dependence is apparent not only in terms of funds to support the social sector and state institutions, but also in terms of development ideas. It is an established fact that despite assertions of ownership, development policy very often reflects the perspectives of creditors or donors. Thus, when strapped for resources, African countries can often find themselves at the receiving end of externally imposed ideas that might not really be in their own perceived interests (Kant, 2002).

Another governance dimension of IFFs relates to the unequal burden of citizenship imposed on other sectors of society, both in terms of tax fairness and 'free-riding'. When large companies, particularly Multi-National Corporations (MNCs), engage in base erosion and profit-shifting activities, the bulk of the tax burden as a result falls on small and medium-scale enterprises and individual taxpayers (Global Financial Integrity, 2008). This runs counter to the idea of progressive taxation, in which those who earn more income contribute a larger percentage of tax revenues. Just as pernicious to governance is the 'free-riding' that results when entities evade or avoid taxes where 
they undertake substantial economic activities and yet benefit from the physical and social infrastructure, most of which is still provided by the public sector in Africa (Global Financial Integrity, 2013a).

The development consequences of IFFs are quite severe. When monies are illicitly transferred out of African countries, their economies do not benefit from the multiplier effects of the domestic use of such resources, whether for consumption or investment. Such lost opportunities impact negatively on growth and ultimately on job creation in Africa. Similarly, when profits are illicitly transferred out of African countries, reinvestment and the concomitant expansion by companies are not taking place in Africa (Kant, 2002).

Further, illicit financial outflows from Africa end in developed countries. Countries that are destinations for these outflows also have a role in preventing them and in helping Africa to repatriate illicit funds and prosecute perpetrators. Thus, even though these financial outflows present a problem to Africans, united global action is necessary to end them. Such united global action requires that agreement be reached on the steps to be taken to expedite the repatriation of the illicitly exported capital. This must include ensuring that the financial institutions that receive this capital do not benefit by being allowed to continue to house it during periods when it might be frozen, pending the completion of the agreed due processes prior to repatriation (Cobham, 2012). Every year, developing countries lose a massive volume of wealth to corruption, tax evasion, and money laundering enabled by IFFs. These funds could help to fill the gap for funding sustainable development.

The consequences of IFFs can be devastating for several reasons. IFFs enable corrupt politicians, public officials, and economic elites to hide their proceeds of corruption. When IFFs are sent overseas, they are likely to reduce the elites' support for the development of the state because less of their wealth is dependent upon the domestic economy (Lain et al., 2017). Further, reduced tax earnings have a direct negative effect on public and private investment as well as the provision of public services. The result is fewer schools, hospitals, jobs, and infrastructure projects, and weaker social protection for the citizens in these countries. IFFs place skewed tax burdens on poor citizens and honest businesses (Transparency International, 2015). Many of the effects of IFFs are circular. For example, if money laundering enables corrupt politicians to safely hide the proceeds of corruption, this will help them to retain power by shielding them from proper accountability, which may further enable them to corrupt the institutions responsible for detecting money laundering and crime (Reed and Fontana, 2011). When weaknesses in the financial system are not regulated effectively, organised crime and illegal economies can thrive.

IFFs also affect other fundamental aspects of development that cannot be captured solely by numbers. First, the rule of law is partly dependent on the support of economic and political elites. If elites can shelter much of their wealth outside the country, they have a lesser stake in the development of, for example, property rights, which is an important aspect of the rule of law. IFFs can therefore have a negative effect on good governance. Second, IFFs can have a negative effect on broader social trust in a society and trust in the government (Reuter, 2017). Bo Rothstein (2016), argues that the elites' use of secrecy jurisdictions to hide away their wealth and avoid taxes can have serious consequences for citizens' trust in institutions:

If the political, economic, social and maybe also the artistic elites behave in the way we have now seen in the Panama money laundering scandal, people will not only lose trust in these elites and the institutions they represent. There is also an additional cost to society that in the long run may have even graver consequences, namely that the basic fabric of social trust is eroded. And trust is a delicate thing, because once lost it is hard to regain. The implication is that we have to account for the existence of a double negative effect from scandals like this (Rothstein, 2016).

There is a close relationship between IFFs and corruption. The literature on IFFs and corruption tends to show that there is a reciprocal causality between IFFs and corruption. Corruption is a source of IFFs and an enabler of money laundering, and money laundering allows for the proceeds of corruption to be hidden away and used. The possibility of moving capital illicitly makes corruption easier to engage in. Moreover, IFFs disproportionally damage state institutions in developing countries, by limiting the provision of public goods and undermining the stability and legitimacy of institutions (Wickberg, 2013). Corruption and IFFs can be linked in several ways. Corruption can be the source of funds (bribes) that constitute illicit funds to be laundered. Illicit funds from corruption can be channelled to a bank account in a foreign country, typically to secrecy jurisdictions, and laundered abroad. Tackling IFFs has the potential to deal with high-level corruption of this kind. Moreover, corruption can be the means of facilitating the creation of IFFs, for example through corrupt tax administrators who ignore illegal tax evasion and other financial obligations. Examples of such corruption can be tax officials who make 'favourable' interpretations of tax regulations to lower a company's tax burden, or tax officials turning a blind eye to tax evasion. Further, corruption can be a means for enabling an IFF via corruption in the institutions with obligations to report on IFFs, for example, when a bank official fails to notify suspicious transactions to the relevant authorities after receiving a bribe (Reed and Fontana, 2011).

\subsection{Actors in Illicit Financial Flows}

There are different actors in the policy sphere of IFFs. These actors have different stakes, with some of them implicated as perpetrators while others are actively engaged in combating IFFs (Haken, 2011). These actors have also different capacities with regard to responding to the policy and regulatory requirements of IFFs and have different levels of information at their disposal. It is important to understand the respective roles, motives and incentives of these different actors, as well as the complex interrelationships between them. These actors include governments within and outside Africa, the private sector, CSOs, criminal networks and global actors such as international financial institutions. The actors are looked at in detail below (Kar, 2010). 


\subsubsection{African Governments}

African governments have a political interest in IFFs because these flows impact their national development aspirations and encroach on state structures. Governments therefore have law enforcement and regulatory agencies whose duties include preventing IFFs. Among these agencies are the police, financial intelligence units, and anticorruption agencies, customs, and revenue services whose purpose are thwarted or hindered by IFFs (Baker, 2005). Most African governments have a strong interest in stemming IFFs, including through obtaining the cooperation, compliance, and commitment of other actors. They seek to stop IFFs in order to maximise tax revenues, keep investible resources within their countries, prevent state capture and impede criminal and corruption activities. Most African governments lack specialised agencies to deal with IFFs. They also lack various capacities in law and finance to tackle IFFs effectively, with unbalanced institutional capabilities in some countries. For example several African countries have set up anticorruption agencies. Policy on IFFs is generally set by one more central government departments which may also play a coordinating role in the implementation of law (Global Financial Integrity, 2008).

\subsubsection{The Private Sector}

The private sector in Africa consists of large companies, small and medium-scale enterprises and the informal sector. The large companies are engaged in all economic sectors such as agriculture, mining, manufacturing and services. These include multinational corporations, international banks, international legal and accounting firms that operate in several African countries. In terms of the financial flows involved, it is the large companies that engage IFFs through abusive transfer pricing, trade mis-invoicing, mis-invoicing of services and intangibles and use of unequal contracts (Moore, 2012). They exploit the lack of information and capacity limitations of government agencies to engage in base erosion and profit shifting activities. Given their scale, IFFs will at some point pass through banks and the financial system. The international banks sometimes facilitate IFFs even when they know that the money is tainted, as became evident in several asset recovery cases. Even where banks have an obligation to file suspicious transactions reports, this requirement is often overlooked in some countries in transactions emanating from small, rural branches (Moore, 2012). In some cases banks sometimes knowingly establish infrastructure to facilitate IFFs moving to financial secrecy jurisdictions. As gatekeepers to the financial system, banks and other financial institutions are supposed to implement a wide range of measures to combat IFFs and are an essential source of information for the government.

\subsubsection{Civil Society Organisations (CSOs)}

CSOs have been actively fighting against IFFs. They have campaigned against IFFs from Africa and other parts of the world from the perspective of social justice and also because of their effects on development and governance. CSOs have used various means to draw attention to the negative consequences of IFFs, ranging from advocacy campaigns and naming and shaming perpetrators to undertaking research and proposing policy solutions. CSOs such as Action Aid International, Global Financial Integrity, Oxfam, Pan African Lawyers Union, Tax Justice Network and Transparency International have been actively fighting against IFFs. However, these CSOs face political pressure and need to be provided with the space and support that will enable them to continue their campaigns (Kar, 2011).

\subsubsection{Criminal Networks}

Criminal networks engage actively in laundering money from Africa, with the motive of hiding their activities, facilitating payments across their illegal supply chains and concealing the resulting illicit wealth. Criminal networks by their very nature minimise contact with law enforcement agencies, tax, customs, and regulatory authorities (OECD, 2014). These networks include maritime piracy, narcotics, arms, human trafficking, and sophisticated people who run the operations, and related financial transactions. Illicit financial transactions are used to finance, and sponsor terrorist organisations such Boko Haram of Nigeria. They also use part of their resources to capture state structures such as the police, tax and customs (Thoumi and Anzola, 2012).

\subsection{The Case of the Panama Papers}

In 2016, 11.5 million confidential documents were leaked from a private legal firm based in Panama. The documents contained information on assets held in offshore companies in more than 40 countries by wealthy individuals, including public officials. Although holding assets in a tax haven is not illegal perse, the prevailing sentiments expressed in newspaper articles and the reaction from the public mainly took the form of condemnation and criticism of a practice interpreted as powerful economic and political elites concealing taxable income from domestic fiscal authorities, with the assistance of the financial systems of many developed countries. After the leak of the documents, the top five European economies (France, Germany, Italy, Spain and United Kingdom) announced actions to improve information sharing in order to fight tax evasion and money laundering. Of these economies, United Kingdom plays a particularly important role in this respect because a number of its Overseas Territories and Crown Dependencies such as the British Virgin Islands and Jersey derive a substantial share of the GDP from providing financial non-resident depositor services. Recently all such offshore jurisdictions have joined this initiative and started to implement rising transparency standards. Panama has also recently taken steps to strengthen its tax transparency and financial integrity frameworks. Fundamental reforms that seemed imaginary just 10 years ago are now being considered as active proposals by powerful bodies such as the G-7 and G-20. These proposals include 
country by country reporting of corporate profits which facilitate detection of transfer pricing abuse and other instruments to shift profits to low tax jurisdictions and the creation of public lists of beneficial ownership to prevent concealment through shell corporations (OECD, 2014).

\section{Methodology}

This study is based on secondary data. Documentary sources included peer reviewed journals, books, book chapters, newspaper articles. Some of the documents consulted included Global Financial Integrity, Transparency International Zimbabwe, Africa by Africa Growth Initiative, African Forum and Network on Debt and Development (AFRODAD), Zimbabwe Anticorruption Commission Reports, and Reserve Bank of Zimbabwe (RBZ), and Zimbabwe National Chamber of Commerce (ZNCC).

\section{Discussion}

The findings presented below are based on documentary search. In Zimbabwe IFFs are mainly underpinned by a number of factors such as legal and institutional lapse in the domestic fiscal and financial systems, leading to corruption and other forms of trade malpractices. Other key drivers of IFFs in the wildlife and fisheries sectors include demand and supply mismatches resulting from price controls, tax and exchange control loopholes. In the mining sector IFFs are mainly a result of corruption, dysfunctional regulations, weak enforcement of rules, tax evasion, and tax avoidance, and smuggling, lack of transparency and accountability in the collection and management of natural resources revenue. The government's limited information on the quantity and quality of geological deposits and shortcomings of the Mines and Minerals Act [Chapter 21:05] create room for rent seeking behaviour and under declarations of quantity and quality of minerals. Such a scenario aids the illicit outflows of money from the county.

It is estimated that during the period 2000 and 2020, Zimbabwe lost in excess of US\$32. 179 billion through IFFs. The unfavourable economic environment in the country and policy changes have resulted in smuggling and money laundering as people try to remit their funds out of the country. According to AFRODAD (2016), Zimbabwe is estimated to have lost US\$2.83 billion through IFFs during the period 2009-2013. This translates to an annual average loss of US\$570.75 million. These IFFs were mainly from mining, timber, fisheries and wildlife. Of the cumulative outflows 97.88 percent (US\$2.793 billion) was from the mining sector. IFFs in wildlife accounted for 0.53 percent (US $\$ 15.07$ million) while fisheries and timber accounted for 0.98 percent (US\$28.04 million) and 0.61 percent (US\$17.30 million) respectively. These estimates are based on the analysis of data sets for partner-country trade from the United Nations Commodity Trade Statistics Data base (UNCOMTRADE) and Convention on International Trade in Endangered Species (CITES). The RBZ estimated a loss of US\$3 billion between 2015 and 2017. The RBZ further posited that an estimated US\$684 million was remitted outside Zimbabwe or externalised under dubious and unwarranted circumstances in 2015. Data from GFI showed that Zimbabwe lost an estimated US\$670 million through trade mis-invoicing in 2015 .

In 2019, the country lost an estimated US\$3 billion to IFFs. The Chairperson of the Zimbabwe Anticorruption Commission (ZACC) in her presentation during the workshop on the Commission's Strategic Plan for 2019-2024 indicated that:

The Financial Intelligence Unit estimated that Zimbabwe lost over US\$3 billion to illicit financial flows through proceeds of crimes involving tax evasion, smuggling, corruption, fraud, drug trafficking and money laundering. Africa loses at least US\$50billion a year.

Transparency International Zimbabwe blamed the flows on the absence of a solid plan that synchronises reforms, arguing that Zimbabwe needed a national anti-corruption strategy to coordinate various governance reforms aimed at curbing corruption and IFFs. In 2018, a list of companies and individuals who had moved funds offshore illegally were published by the Reserve Bank of Zimbabwe. The list indicated that the country had lost close to US\$1 billion.

The Zimbabwe National Chamber of Commerce argued that companies were driven into illicit actions by the tough business environment. It mentioned that:

Confidence in the banking system is relatively low. Because of the loss of value due to high inflation, any Zimbabwean businessperson would rather hold a US dollar account rather than an RTGS dollar (the local currency) to preserve value.

The Africa by Africa Growth Initiative Report (2020) indicated that:

We find a positive and significant relationship between Gross Domestic Product (GDP) and illicit financial flows (aggregate). Inflation is also positively correlated with aggregate illicit financial flows. These findings could indicate that macroeconomic fluctuations such as inflation weaken confidence in a country's macroeconomic environment and encourage people to send their capital abroad. We further find a positive and significant correlation between illicit flows as a share of trade and tax revenue as a share of GDP. Likewise we find a positive and significant correlation between illicit flows as a share of GDP and tax revenue as a share of GDP. When governments collect a large share of taxes, individuals and corporations have incentives to store capital abroad, away from government appropriation. 


\section{Conclusion}

The problem of IFFs is a global phenomenon that requires effort at country, regional, continental and global level. Combating IFFs requires concerted efforts by both developed and developing countries. Zimbabwe should put greater emphasis on measures aimed at regulating secrecy jurisdictions, strengthening anti-money laundering efforts, enhancing tracking of financial crimes, and corruption. Zimbabwe should also strengthen its legal and institutional frameworks that are fit for purpose; credible; enforceable and adaptable to the dynamic and complex illicit activities that facilitate IFFs. Penalties for offenders should be deterrent and incentive compatible. Institutions created to deal with economic crimes, such as the Zimbabwe Anticorruption Commission (ZACC), Financial Intelligence Unit (FIU), Reserve Bank of Zimbabwe (RBZ), Zimbabwe Republic Police (ZRP), and the National Prosecuting Authority (NPA), must be given enough degrees of freedom and autonomy to operate freely without political interference. These institutions should be well resourced and staffed with well-motivated and technically competent personnel to investigate and deal with complex issues of IFFs.

There is also need for a global approach. This will entail dealing with cases of excessive financial secrecy that allows tax evasion, money laundering, terrorist financing or other criminal activities. Most developed countries benefit from financial secrecy or tax avoidance at the expense of poor countries. Reforms in the international financial architecture, requiring greater transparency in the banking system could be a giant step towards addressing the problem of IFFs. Banks should be obliged to ascertain the identity, source of wealth, and country of origin of their customers and their deposits. This will enhance greater transparency, to the detriment tax havens, which thrives in secrecy. Further, such mechanism will not only discourage IFFs but will also help in the repatriation of stolen assets, as well as enforce compliance with tax laws of respective countries.

\section{References}

AFRODAD (2016). Annual report. Available: www.afrodad.org

Baker, R. W. (2005). Capitalism's achilles heel: Dirty money and how to renew the free-market system. John Wiley and Sons: Hoboken, NJ.

Blankenburg, S. and Khan, M. (2008). Governance and illicit financial flows. In P. Reuter (Ed.). Draining development? Controlling flows of illicit funds from developing countries. The World Bank: USA.

Blankenburg, S. and Khan, M. (2012). Governance and illicit flows in Reuter, P. (ed.) draining development? Controlling flows of illicit funds from developing countries. World Bank: Washington, D.C: 21-68.

Cobham (2012). Financial crisis and quantitative easing: Can broad money tell us anything. Money, Macroeconomics and Finance, 80(1): 54-76.

Cobham (2014). The impacts of illicit financial flows on peace and security in Africa, study for tana high-level forum on security in Africa 2014 and uneca report. 17.

Dolve, M. H. M. and Mullard, S. (2018). Addressing illicit financial flows for anti-corruption at country level: A primer for development practitioners. CCHR Miclsen Institute: Norway.

Epstein, G. A. (2005). Capital flight and capital controls in developing countries. Edward Elgar: Cheltenham, U.K.

Erskine, A. and Eriksson, F. (2018). Improving coherence in the illicit financial flows Agenda. Available: www.u4.no.publications.org

Fontana, A. and Hansen-Shino, K. (2012). Implementing the illicit financial flows agenda: Perspectives from developing countries. Available: $\underline{w w w . c m i . n o}$

Global Financial Integrity (2008). Illicit financial flows from Africa: Hidden resource for development. USA: Washington DC.

Global Financial Integrity (2013a). Explore the Data: Illicit Financial Flows from Developing Countries 2002-2011. How to Read the Report's Findings, USA: Washington, D.C.

Global Financial Integrity (2017). Illicit financial flows to and from developing countries: 2005-2014. USA: Washington DC.

Haken, J. (2011). Transnational crime in the developing world. Global Financial Integrity: Washington D.C.

Kant, C. (2002). What is capital flight? The World Economy, 25: 341-58.

Kar, D. (2010). Illicit financial flows from Africa: Hidden resource for development. Global Financial Integrity: Washington, DC.

Kar, D. (2011). Illicit financial flows from the least developed countries: 1990-2008. United Nations Development Programme New York.

Kar, D. and Freitas, S. (2012). Illicit financial flows from China and the role of trade Misinvoicing. Global Financial Index: USA.

Lain, S. H., Campbell, H., Moiseienko, A., Nouwens, V. and de Oliveira, I. S. (2017). Illicit financial flows and corruption in Asia. RUSI - Royal United Services Institute.

Manton, J. and Daniel, T. (2012). The Kleptocrat's Portfolio Decision in Reuter (Ed.).Draining development? Controlling flows of illicit funds from developing countries. The WorldBank: USA.

Moore, M. (2012). The practical economy of illicit flows. In. Reuter, P., ed. Draining development: Controlling flows of illicit funds from developing countries, USA: Washington DC.

OECD (2014). Standard for automatic exchange of financial account information: Common reporting standard. OECD: Paris.

Organisation for Economic Co-operation and Development OECD (2013). Measuring OECD responses to illicit financial flows. OECD: Paris. 
Ostfeld, S. (2013). Why UN arms negotiations must include talk of ending corporate secrecy. Available: www.aljazeera.com

Reed, Q. and Fontana, F. (2011). Corruption and illicit financial flows. The limits and possibilities of current approaches. U4 Anti-Corruption Resource Centre: Bergen. 4: 2.

Reuter, P. (2012). Draining development? Controlling flows of illicit funds from developing countries. World Bank.: Washington, DC.

Reuter, P. (2017). Illicit financial flows and governance: The importance of disaggregation. World Bank. World Development Report: Background Paper.

Rothstein, B. (2016). The Panama papers have further undermined our trust in institutions. Capx.

The Zimbabwe Independent (2020). Illicit Financial Flows: Zim Loses US\$32 Billion. Available: www.zimindependent.co.zW

Thoumi, F. E. and Anzola, M. (2012). Can AML policies succeed in Columbia. Crime, Law and Social Change, 57(1): 1-14.

Transparency International (2015). Corruption perception index. Available: www.transparency.org

UNODC (2011). Estimating Illicit financial flows resulting from drug trafficking and other transnational organised crimes. Research Report.

UNODC (2012). World Drug Report 2012. Available: www.un.org

Wickberg, S. (2013). Literature review on the linkages between illicit economy and corruption. U4 Expert Answer. U4 Anti- Corruption Resource Centre: Bergen. 396. 